\title{
КОНЦЕПТОСФЕРИ ФАУНИ І ФЛОРИ В ПРОЗОВИХ ТВОРАХ ДЛЯ ДІТЕЙ М. ВІНГРАНОВСЬКОГО
}

\author{
ОЛЕНА ГОМЕНЮК \\ Тернопільський національний педагогічний \\ університет імені Володимира Гнатюка, \\ Тернопіль - Україна

\section{KONCEPTOSFERY FAUNY I FLORY W PROZATORSKICH UTWORACH DLA DZIECI MYKOEY WINHRANOWSKIEGO} \\ OLENA HOMENIUK \\ Tarnopolski Narodowy Uniwersytet Pedagogiczny im. W. Hnatiuka, \\ Tarnopol - Ukraina
}

STRESZCZENIE. W artykule poddano analizie faunę i florę jako odrębne konceptosfery w prozatorskich utworach dla dzieci Mykoły Winhranowskiego. Wyodrębniono w ich strukturze mikrokonceptosfery oraz koncepty główne będące reprezentantami autorskiego obrazu świata. Dokonano analizy autorskich konceptów — „wiąz” („,berest”) oraz „wrona” (,worona”).

\section{CONCEPT SPHERE OF FAUNA AND FLORA IN M. VINHRANOWSKYI'S PROSAIC WORKS FOR CHILDREN}

\author{
OLENA GOMENIUK \\ V. Hnatiuk Ternopil National Pedagogical University, \\ Ternopil - Ukraine
}

ABSTRACT. The article is dedicated to the analysis of the concept sphere of fauna and flora in M. Vinhranovskyi's prose for children. The micro concept spheres and core concepts, which are the main representatives of the author's mapping of the world, have been traced in the structures of the concept sphere of fauna and flora. This article analyzes two individual author's concepts - ELM and CROW.

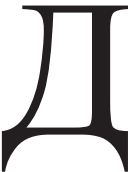

ослідження концептів активізувало інтерес науковців до таких понять, як „концептуальний аналіз”, „концептуалізація”, „концептосфера”. На здатність концептів взаємодіяти та об'єднуватися в певну систему звертало увагу багато вчених, кваліфікуючи різні об'єднання концептів, як „концептосфера”, „концептуальна система”, „концептуалізована ділянка”, „концептуальне поле" та ін., часто використовуючи подібні терміни як синонімічні.

Частіше концептосферу визначають як „складну структуровану цілісність”, „систему думок і знань про світ, що відображає пізнавальний досвід людини, причому як на домовному, так і на мовному етапах, але не зводиться до будьякої лінгвістичної сутності"'2.

${ }^{1}$ В . I. Ко н о н ен ко , Концепти українського дискурсу, Київ-Івано-Франківськ 2004, с. 21.

${ }^{2}$ М.М.Положин, Концепт як базова когнітивна сутність, [в:] Мовні і концептуальні картини світу, Київ 2001, с. 184. 
Думку Д. Лихачова про те, що не всі мовці однаково можуть збагачувати концептосферу національної мови й що важлива роль у її створенні належить письменникам, насамперед поетам, розвинули автори енциклопедії Українська мова, зауважуючи, що в концептосферу входять навіть назви творів, що через свої значення породжують концепти. „Сукупність лінгвокультурних концептів формує концептосферу окремої людини, груп людей, етносу”з. Порівняймо з лихачовським: „Концептуальна сфера, в якій живе будь-яка національна мова, постійно збагачується, якщо є гідна ії література й культурний досвід. Вона важко піддається скороченню, й то лише тоді, коли пропадає культурна пам'ять у широкому розумінні цього слова"4.

Специфіку авторських концептосфер вивчали Т. Космеда (Т. Шевченка), К. Голобородько (О. Олеся), Н. Мех (Г. Сковороди), А. Башук (М. Гумільова), В. Маслова (М. Цветаєвої) та багато інших. Про вплив художньої літератури на формування концептосфер пише Т. Вільчинська: „Концептуальна сфера, в якій живе будь-яка національна мова, постійно змінюється та збагачується завдяки наявності необхідного культурного досвіду, зокрема розвитку словесного мистецтва"5. Саме тому актуальним на сьогодні $є$ дослідження не лише окремих концептів у творчості видатних митців художнього слова, а й концептосфер, що формують індивідуально-авторську картину світу.

Мета запропонованого повідомлення полягає в тому, щоб з'ясувати специфіку об'єктивації концептосфер флори й фауни в прозових творах для дітей М. Вінграновського. Отже, матеріалом дослідження послужили прозові художні тексти цього письменника, написані ним для дітей і про дітей.

За словами українського кінорежисера Павла Щириці, мова творів М. Вінграновського „створює ауру дивовижної музики, що відлунює в тобі і бринить повсякчас досконалим суцвіттям мови, кодом національної краси і сили, дотепністю й правдоподібністю нестримної фантазії - власне звучанням української землі"б.

Високу оцінку прози М. Вінграновського дав $Є$. Гуцало: „Людина й земля, світ людини і світ природи - невіддільні, вони щільно змикаються, становлячи цілісну сутність. Світ природи існує не поза сприйняттям людини, а тільки в її свідомості, цей світ олюднений, живий, він начебто наділений своєю загадковою душею, своєю специфічною свідомістю. Читаючи прозу М. Вінграновського, подеколи не можеш позбутися відчуття, що за таємницями й загадками довколишньої природи стають, власне, не так таємниці, як загадки, як активний цілеспрямований розум, і людина намагається через зовнішні вияви осягнути сокровенні внутрішні його параметри"7.

Однією із найсуттєвіших ознак прози М. Вінграновського $є$ поетизація світу природи. Поетично схоплені реалії письменник начеб приміряє до життя. Інакше кажучи, „накладає” їх на об'єктивну дійсність, проявляючи при цьому велику майстерність, що читач не відчуває ні в чому ніякої „підробки”. У нього виникає виразне емоційно-оцінне ставлення до всього описуваного 8 .

${ }^{3}$ Украйнська мова: Енциклопедія, редкол.: В. М. Русанівський, О. О. Тараненко та ін., Київ 2007, с. 285.

${ }^{4}$ Д. С. Л и х ач е в, Концептосфера русского языка, [в:] Русская словесность. От теории словесности к структуре текста: антология, Москва 1997, с. 286.

${ }_{5}^{5}$ П. Щ и р и я, Материк Вінграновський: незнаний і незникомий, [в:] „Літературна Україна” 2011, 10 лист, с. 10.

${ }^{6}$ Є. Гу ца л о, I так ми всі родимо, і так ми всі ивітемо, [в:] „Літературна Україна” 1980, 12 верес, с. 8.

${ }^{7}$ Т. Ю . С а л и г а, Микола Вінграновський: літературно-критичний нарис, Київ 1989, с. 144.

${ }^{8}$ Н. Сологуб, Кінь на вечірній зорі (мова художньої прози М. Вінграновського), [в:] „Культура слова” 2011, вип. 75, с. 16. 
Концептосфери фауни і флори в прозових творах для дітей М. Вінграновського 81

На те, що одним із основних концептів у мовотворчості М. Вінграновського є природа, звертає увагу Н. Сологуб, яка лексику на позначення садових реалій розглядає як окреме лексико-семантичне поле 9 . Коли природу розуміти як мегаконцепт, то цілком логічним виглядає виділення в його межах концептів на позначення рослинних і тваринних образів, як і логічним виглядає об’єднання їх у дві концептосфери — „флора” і „фауна”.

У концептосфері „флора” розмежовуємо три мікроконцептосфери, розуміючи під нею, як Т. Космеда і Н. Плотнікова, „фрагмент ККС, сформований на основі уявлень та репрезентований сукупністю одиниць пам'яті (концептів), що групуються за тематичною ознакою”", а саме: „дерева”, „трав’янисті рослини” і „назви городини”. До першої належать концепти на позначення дерев; друга об'єднує концептуалізовані образи квітів, трав та злакових культур; третя охоплює концепти рослин, вирощених на городі, баштані тощо.

У кожній із мікроконцептосфер, зважаючи на досліджуваний матеріал, визначаємо ядерні концептуалізовані одиниці. Так, у мікроконцептосфері „дерева” до них належать такі, як: „груша” (То ц̧віла мені груша на останньому цุвіті зими)"1; „дуб” (Ми тут кожен горбик обчовгали своїми животиками і на кожному дубі в дозорі сиділи (с. 297)) і „берест” (Мені й самому дивно, чого ие раптом став берестом і чому саме берестом, а не іншою деревиною (с. 322)). У мікроконцептосфері „трав’янисті рослини” - це концепти „очерет” (3 мідного очерету на срібне кодимське плесо висунувся чорний ніс каюка... (с. 341)); „будяк” (... довгов'язому будяку збили в траву його малинову квітку й занурилися [мисливиі], наче пінгвіни, в ближчі до Кодими очерети (с. 13)) та „кульбаба" (Маня з жовтою кульбабою в губах з того лисячого боку озера дивиться на тебе i cmoїmь (с. 184)). До ядерних у мікроконцептосфері „назви городини” зараховуємо концепти „буряк” і „кавун”, семантика яких об’ єктивується в численних контекстах та засвідчує індивідуально-авторські уподобання: Хай живе Всесвітній День Буряка! (с. 37); Ось він [кавун] лежить у темній товстостеблій мушійці, щуо своїми коричневими качалочками чіпляється і пристає до цтанів, - через те, мабуть, його тут ніхто не вгледів!.. (с. 107)).

Особливу увагу в мікроконцептосфері ,лерева” привертає концепт „берест”, який у досліджуваних текстах зазнав помітної авторської інтерпретації. Берест в етнокультурі українців не характеризується такими яскравими символічними значеннями, напр., як дуб чи верба, хоча має досить тривалий вік (до 300 років) та корисні властивості деревини (з якої роблять музичні інструменти).

Номінативне поле концепту, що вживається на його позначення, представлене відповідною флоролексемою - берест: Батько не знає, щзо изей берест ие я, його середній син (с. 322). Хоча в українській мові відомі ще назви в яз, карагач.

Слово берест точно відповідає гот. baiŕhts, д.-в.-н. beraht 'світлий, сяючий', споріднене зі словом береза ${ }^{12}$. У СУМі представлено два ЛСВ до лексеми беpecm: „1. Листяне дерево з коричнево-сірою корою і овальними, на кінці загостреними листками, яке використовують для живоплотів та захисних лісонаса-

${ }^{9}$ Т. А. Космеда, Н. В.Плотнікова, Лінгвоконцептологія: мікроконцептосфера СВЯТКИ в украӥнському мовному просторі, Львів 2010, с. 31-32.

${ }^{10}$ М. С. В інгранов ський, Вибр. твори: Повісті й оповідання, Тернопіль 2004, т. 3, c. 310 - далі подаємо поклики на це видання в круглих дужках, зазначаючи конкретну сторінку.

${ }^{11}$ М. Ф а с мер, Этимологический словарь русского языка в 4 m., Москва 1986, т. 1, с. 156.

${ }_{12}$ Словник української мови в 11 m., ред. І. Білодіда, Київ 1970, т. 1, с. 160. 
джень; 2. Кора, луб берези"13. В аналізованих текстах об'єктивується насамперед перше значення, через яке втілюється концептуальний смисл ,те, що відповідає одному із видів листяних дерев": Зараз батько прив'яже корову до береста на причілку хати (с. 322).

Семантика концепту „берест” найбільш повно розкривається в оповіданні М. Вінграновського Наш батько, де письменник від імені синів, які загинули на війні, розповідає історію однієї української сім’ї. Один із синів перетворився в поле, що простяглось біля їхнього рідного села: Мене нема. Тобто оце поле, на якому наш батько випасає череду, це я $і$ є. Мій літак вибухнув у повітрі, $i$ я осипався на землю вже попелом... (с. 324); інший - став берестом: В одному з боїв я впав на міну $і$ виріс оце коло нашої хати берестом... Берест изея, його [чоловіка] середній син (с. 322). У контексті з лексемою-вербалізатором берест через позиції суб'єкта й об'єкта зіставлення реалізується два концептуальних смисли - „хлопець як берест” і „берест як син”.

Дерево гармонійно співіснує 3 навколишнім світом, про що свідчить семантичний компонент ,той, що розчинився в природі”: На причілку кузні ріс берест: обліплений снігом, берест злився з усім білим навколишиям, $і$ Сашко відразу його не помітив (с. 75). У структурі концепту його увиразнює смисл „той, якого люблять птахи": Птахи люблять мене [береста] (с. 323).

Як частина органічного світу природи, берест стає домівкою для птахів, на його листі знаходять пристанище вітер, сніг та мороз. Уявлення про це експлікуються в концептуальному смислі „,той, що є локусом для птахів, вітру, снігу тощо": Завжди в моєму листі вітер якийсь ночує, взимку то сніг, то мороз гніздечко тремтить на мені одиноке... (с. 323).

М. Вінграновський захоплюється берестом, який своїми , гілками і листом видався нівроку”, та найбільше вражає письменника, коли той радіє, що в його кронах оселилися пташки, в яких скоро буде потомство: Гілками і листям видався я [берест] нівроку, і то найкраща для мене пора, коли на мені у гнізді яка птаха сидить на яйиях... (с. 323). У цьому контексті об'єктивуються смисли „той, що є міцним і розкішним”, „який радіє народженню нового життя”.

Змальовуючи картини природи, письменник орієнтується на дитячу аудиторію, тому його герої часто не лише милуються красою дерев та ласують їхніми плодами, а й використовують їх як місця для ігор чи оглядових веж. Це в структурі аналізованого концепту демонструє семантичний компонент „той, біля якого люблять гратися діти”: Сашко скинув на сніг кожушину, хукнув у долоні, щзе раз оглянувся, поліз на берест (с. 75).

Символізація береста простежується в його асоціаціях із батьківською хатою, рідною „благодатною” землею: 3 изієї миті, як я став берестом, я почуваю себе прекрасно. Земля піді мною така, щзо коріння у ній аж співає, - така це земля благодатна (с. 323). Тут концепт реалізує смисл „той, що асоціюється з рідним краєм".

Ставши берестом, хлопець утрачає мову, можливість пересуватися, не може навіть заснути (Відколи я таким став, я не можу заснути (с. 323)), проте душа у нього залишається, як і раніше, людською. Йому так хочеться поговорити з батьком, признатися, що він його син: Сказати батькові, щзо я-ие я, берест, я вже не можу, бо листя моє не говорить по-людському, а вітром хіба чи дощеем - то інше діло (с. 323). У наведеному контексті імплікується та експлікується декілька концептуальних смислів: „той, що відчуває сум, самотність”,

\footnotetext{
${ }^{13}$ Словник украйнської мови..., с. 740.
} 
Кониептосфери фауни і флори в прозових творах для дітей М. Вінграновського 83 „зберігає людську душу” (супроводжують конотації співчуття, жалю) і „який не втрачає надії”.

Наростання напруги демонструє контекст, в якому батько, втративши надію побачити синів живими, починає думати про смерть і хоче зробити з береста собі домовину: ... а батько візьми та й скажи: немає у мене, крім череди, нікого, оце допасу до зими, та спиляю оцього береста, та витну собі домовину із нього, помру, а хату передам у колгосп (с. 323). Тут імплікуються відчуття болю й жалю, що їх переживає самотній батько, та символізується берест як уособлення кінця, що рано чи пізно таки настане.

Загалом мовна концептуалізація береста засвідчила, що в досліджуваних текстах він об'єктивується передусім як індивідуально-авторський концепт. 3 одного боку, на це вказують смислові компоненти в структурі відповідного концепту, а з іншого, - численні лінгвальні засоби його презентації. Найчастіше автор послуговується метафорами („,гніздечко тремтить на мені”, „в листі моєму вітер ночує”) і порівняннями (,виріс берестом”, ,листя говорить вітром хіба чи дощем"), рідше - іншими засобами.

Дві мікроконцептосфери - „тварини” і „птахи” - розрізняємо в концептосфері „фауна” М. Вінграновського. Ядерними компонентами в першій є концепти на позначення свійських та диких тварин, зокрема такі, як: „кінь” (Задрiмала й Манюня. Вона завжди дрімала стоячи. Лежачою я ніколи ї̈ не бачив як і кожен при силі кінь, до старості літ вона спатиме на ногах... (с. 10)); „корова" (Так вони і трусилися з коровою на спорожнілому базарі, на сірій землі під сірим небом (с. 150)); „собака” (Біля криниці лежав отой самий степовий собацюра $i$, ледве котра ж жінок наближалася з відрами до криниці, шкірив зуби й гарчав (с. 159)) і „вовк” (Уночі прийшла осінь, і вовк хмукнув сизий листок ожини, хмукнув і сказав: „Ого-го!” (с. 61)).

До ядерних у мікроконцептосфері „птахи” належать концепти „гуска” (Гуска зачаїлась, коли вітер удруге нагне очерет і вона скубне із нього іще хоч листочок, та вітер раптово повернув і поклав очерет на порожні гнізда (с. 286)); „сорока” (Так само і по-державному споглядала дідка сорока, щзо злетіла з гнізда і всілась на кінчик прапора (с. 53)); „ворона” (Тоді залетіла одна ворона, друга, політали низько над вовком, подивились на вишкірені його зуби (с. 86)) і ,лелека" (Це вже я добре помітив, щзо и̧ілу весну і літо наш лелека спить на одній нозі (с. 328)).

Для прикладу розглянемо концепт „ворона”, який також в аналізованих текстах набуває виразного індивідуально-авторського забарвлення. М. Вінграновський часто зображає цього птаха, частіше зграю птахів, що демонструє контекст: На ріку накинулися ворони і сороки. Зголоднілі за зиму, з бойовим, невтомним карканням і скрекотінням вони роздзьобували річку на очах... (с. 113) (зауважимо, що тут простежується одразу два концептуальні смисли „ті, що $є$ ненаситними” та „які видають специфічні звуки”).

Основним вербалізатором досліджуваного концепту є слово ворона. У загальномовній практиці представлене двома значеннями: „1. Хижий птах із чорним або сірим пір'ям, що живе на деревах поблизу населених пунктів; 2. перен., зневажл. Про неуважну людину; гава, роззява"14. У досліджуваних текстах концепт, номінований цією назвою, реалізує перше із них, напр.: Одна така тонка ворона крикнула так, щзо я відкрив очі (с. 122).

${ }^{14}$ М. Ф асме р, Этимологический..., с. 353. 
Походить лексема від праслов'янського *vorna, споконвічно споріднене із литовським várna: ворона визначається як пов'язана із вороном ${ }^{15}$. Цим, очевидно, можна пояснити і вживання номена ворон: Ворон ішов важко, наче мав на ногах пудові чоботи (с. 86). Також поширеною в досліджуваних текстах є форма множини - ворони: Деякі із ворон, ніби щось згадавщи, не хотячи, не кваплячись, обпираючись на крилах вскакували у відкритий люк $і$ там, у баштані, щось робили, бо їх звідти довго не було видно... (с. 114).

Змальовуючи ворону, автор помітно відступає від етнотрадицій, розширюючи в такий спосіб семантику відповідного концепту. У народних віруваннях чітко простежується диявольська природа сім'ї воронячих. Так, „вважають, що ворона чорна тому, що вона створена дияволом. Чорт може приймати подобу чорного ворона або ворони. В образі ворона чорт літає вночі по дворах і запалює стріхи. Вірили, що чорти у подобі воронів злітаються і кружляють над будинком чаклуна, який помирає, щоб допомогти його душі вийти з тіла. Вважалося, що відьму можна розпізнати по чорному ворону, який прилітає до іï хати" ${ }^{\prime 6}$. Подібні уявлення не знайшли свого вираження в прозі для дітей М. Вінграновського.

Ворона уособлює в українській етнокультурі щось „дурне, погане, недобре, некрасиве тощо, частіше вживається на позначення негарної жінки, рідко - чоловіка... На грунті негативного сприйняття в слові ворона виділилися семи „гава”, „роззява”, „той, що безтямно щось робить” ${ }^{17}$. Лише з останнім із них пов'язана об'єктивація досліджуваного концепту. Це підтверджує контекст: Тепер ия рожева бурякова пляма мандрує на голубій крижині $i$ чорна ворона довбе ї̈ дзьобом (с. 114).

Більшу частину структури концепту „ворона” становлять індивідуальноавторські смисли. Незважаючи на те, що в народних уявленнях птах символізує частіше розгубленість, неуважність, страх, в аналізованих текстах експлікуються аксіологічно протилежні смисли, як-от: „ті, що стежать за собою”, „цікаві і спостережливі": На баштані чистили пера ситі, вдоволені ворони, з її пливучої висоти споглядали наме сіре, в хатах $і$ землянках, село (с. 114), а також „та, що є сміливою": Погойдали носами, хвостами [ворони], і тоді одна із них, найбільша, очевидно ворон, пішла до вовка (с. 86); „хитрою і підступною, за що не раз страждає": Якась ворона ухитрилася вхопити його за вухо, підняла $і$ понесла над крижинами на той протилежний берег, та лисенятко вивернуло мордочку догори і вкусило ворону за лапу (с. 115); „спритною”: Якась ворона літала з ложкою. Та ия була за сороку спритніша: як тільки, щзоб відібрати, на неї налітали інші ворони, вона тією ложкою била їх по дзьобах (с. 113).

Як і берест, ворона є органічною частиною світу. Звідси їі прагнення все пізнати: вона виявляє інтерес як до людей (дітей), так і до інших звірів. У структурі концепту це засвідчують смисли „та, що прагне спілкування”: Чомусь прилетіла ворона. Покружсляла над вовком, сіла недалеко і сказала: „Кра!” (с. 85); „живе поблизу людей”: На баштані чистили пера ситі, вдоволені ворони, з ї̈ пливучої висоти споглядали наме сіре, в хатах $і$ землянках село (с. 114).

Часто семантика концепту реалізується через різні тропеїчні структури, передусім епітети, порівняння та метафори. Напр., епітет чорні, конотує смисл „та, що характеризується чорним кольором”: А наді мною розлогими повільни-

\footnotetext{
${ }^{15}$ В. М. Войто вич, Українська міфологія, Київ 2002, с. 401.

${ }^{16}$ В. І. Кон онен ко, зазн. джерело, с. 139.

${ }^{17}$ Т. Ю. С алиг а, зазн. джерело, с. 144.
} 
ми колами, високо-високо, одна за одною, строго по порядку, ковзаються, наче на ковзанах, по синьому небу чорні весільні ворони (с. 112). Подібне стосується й авторських епітетів ситі, вдоволені, весільні або тонка, найбільша, через які есплікуються відповідні концептуальні ознаки. Автор порівнює ворон із ведмедями (Ворони і ті літали по харч важко, наче ведмеді (с. 203)); зіставляє ворону із сорокою, причому на користь першої (Якась ворона літала з ложкою. Та ия була за сороку спритніша... (с. 113)) та ін. Через метафори інформує про поведінку цих птахів (,ковзаються... по синьому небі”; ,роздзьобували річку на очах" та ін.).

Щоб надати оповіді реалістичності, М. Вінграновський звертається до народної творчості, зокрема використовує рядки з української пісні: Ой щзо ж то ай за ворон, щзо по морю кряче!.. (с. 54) (імплікується смисл „той, що є самотнім").

Отже, концепт „ворона” в досліджуваних текстах акумулював смислові компоненти, що передають етнокультурні та індивідуально-авторські уявлення про цього птаха та засвідчують амбівалентність концептуалізованої структури. Загалом прозові твори для дітей М. Вінграновського наскрізь пронизані рослинними й тваринними образами, що стали важливими сюжетними компонентами. Письменника „хвилює не лише „зовнішня” краса природи, а й ії так звана „внутрішня сутність”, те, як вона відтворюється у свідомості людини, які почуття й думки викликає, як впливає на почуття і поведінку його персонажів"18. Досліджуючи лінгвоментальну специфіку концептів зі сфери флори й фауни, можна змоделювати індивідуально-авторську картину світу М. Вінграновського та порівняти іiі з етнонаціональною, в чому й вбачаємо перспективу подібних досліджень.

${ }^{18}$ Т. Ю. С ал иг а, зазн. джерело, с. 144. 